\title{
A Natureza da Liberdade
}

\section{Dissertação 1}

Breno Ramos Mosso 07/44573

$16 / 2 / 2010$ 


\section{SUMÁRIO}

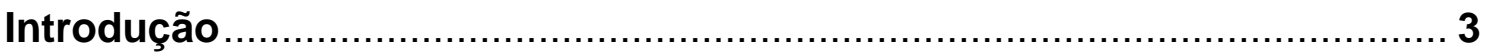

Agostinho: A liberdade da vontade ..................................................... 4

Descartes: A liberdade de Escolha ..................................................... 10

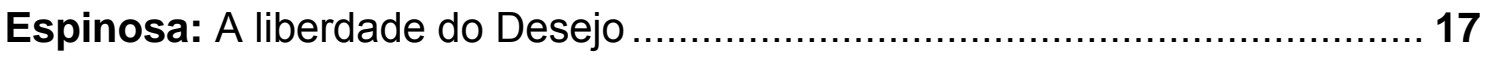

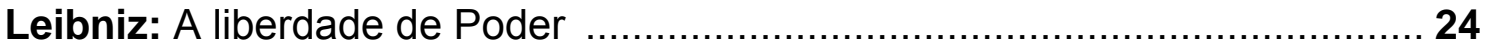

Conclusão: A liberdade Existe? ........................................................ 32

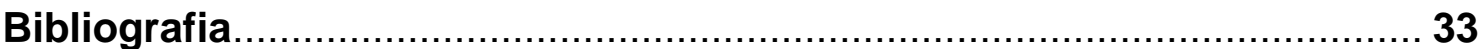




\section{INTRODUÇÃO}

A liberdade parece estar em conflito com o determinismo científico. 0 determinismo pode levar à afirmação de que ninguém é responsável por nada e que nossas ações são completamente determinadas por causas anteriores e, portanto à conclusão de que tudo na natureza é de ordem material. Agostinho defende que se a vontade do homem não estivesse livre, então ele não teria mérito nem culpa. Descartes que age com maior liberdade quem melhor compreende as alternativas em escolha. Spinoza que ser livre é fazer o que segue necessariamente a natureza do agente. Leibniz que o agir humano é livre a despeito do princípio de causalidade que rege os objetos do mundo material.

Essa dissertação discute a natureza da liberdade remontando argumentos de Agostinho, Descartes, Spinoza e Leibniz buscando encontrar o poder do homem fazer as suas próprias escolhas independentemente do encadeamento lógico das suas alternativas. Pois se o homem não é livre, então a vida nada mais é do que um romance escrito sendo vivido por nós a cada página ou um programa de computador auto-executado e todos vivemos nessa ilusão de que estamos fazendo escolhas, quando na verdade só há uma única realidade possível. Por outro lado se tudo for contingente de que valeriam as nossas escolhas? Nenhum poder teria o homem de fazer valer o seu desejo e se determinar.

Entender qual a medida da nossa liberdade de pensar, querer e agir conforme o poder da nossa vontade é esse o objetivo desse trabalho. 


\section{SANTO AgOSTINHO:}

\section{A LIBERDADE DA VONTADE}

\section{A Liberdade em Agostinho}

A maior de todas as liberdades que o homem pode ter é a liberdade de sua vontade, precisamente é dessa liberdade que trata Agostinho. Na sua obra o livre-arbítrio procura ele dar uma resposta à origem do mal o colocando como conseqüência direta do nosso livre-arbítrio. Os Maniqueus defendiam que havia dois elementos misturados no coração de todos os homens um tenebroso e outro luminoso em conseqüência disso todo o mal que fazemos não é praticado por nós, mas o princípio do mal, cativo em nós. Desse modo nossa consciência ficava livre do complexo de culpa, o homem não seria livre em suas ações, toda a responsabilidade humana seria uma ilusão. Acreditando que o mal não poderia provir de Deus, mas sim do próprio homem, Agostinho escreve o livrearbítrio.

Para ele cometer o mal não é nada mais do que submeter sua vontade às paixões, ou preferir aos bens propostos pela eternidade em Deus uma satisfação unicamente pessoal e efêmera. E isso só é possível pela livre opção

da nossa vontade. O homem é livre para fazer o bem e não é forçado a cometer o mal por nenhuma necessidade. Se o homem peca, a culpa é sua. Sem o livre-arbítrio não haveria mérito, nem desmereço, glória ou vitupério, responsabilidade ou irresponsabilidade, virtude nem vício. 
A liberdade aqui é a liberdade da vontade, poderia então Deus impedir ao homem que praticasse o mal e fazer assim que haja apenas o bem no mundo? Mas se ele fizesse isso que sentido haveria em recompensar aqueles que procedem bem e castigar aqueles que praticam o mal. Cabe a cada um escolher entre os bens eternos e os bens temporais. Feliz é o homem de boa vontade e infeliz é o homem de má vontade. No dizer de Agostinho:

Logo, que motivo existe para crer que devamos duvidarmesmo se até 0 presente nunca tenhamos possuído aquela sabedoria- que é pela vontade que merecemos e levamos uma vida louvável e feliz; e pela mesma vontade, que levamos uma vida vergonhosa e infeliz? (Agostinho, 1995, pág.59)

Em teoria os argumentos aduzidos por Agostinho no livre-arbítrio apelam para uma autodeterminação absoluta da vontade. Está em nosso poder o querer ou o não querer agir conforme as nossas boas intenções a despeito de seus impulsos resistentes e linhas de conduta que podem parecer irreversíveis. O homem é livre na sua vontade.

Portanto, se por nossa boa vontade amamos e abraçamos essa mesma boa vontade, preferindo-a a todas as outras coisas, cuja conservação não dependa de nosso querer, a conseqüência será, como indica a razão, que nossa alma esteja dotada de todas aquelas virtudes cuja posse constitui precisamente a vida conforme a retidão e a honestidade. De onde se segue esta conclusão: todo aquele que quer viver conforme a retidão e honestidade, se quiser pôr esse bem acima de todos os bens passageiros da vida, realiza conquista tão grande, com tanta facilidade que, para ele, o querer e o possuir serão um só e mesmo ato. (Agostinho, 1995, pág.61)

É a vontade do homem livre. A persistência do mal na vontade humana é explicada por Agostinho nos seus primeiros sermões como padre como uma força irresistível do hábito tirando esse seu poder do funcionamento da memória humana.

Agostinho elucida a questão de por que alguns serem infelizes e outros serem felizes já que a felicidade está no poder da nossa vontade. Para ele a 
diferença está no merecimento. Todos querem a vida feliz, mas nem todos querem pagar as conseqüências da felicidade -0 fato de viver retamente. Ou seja, a vontade é livre, mas nem todos pesam as mesmas coisas ao fazer as suas escolhas e por isso nem todos obtêm o que querem, muitos sucumbem aos bens de grau inferior, perdendo assim os bens mais duráveis.

Não há, pois, nada de contraditório ao raciocínio precedente: todos querem ser felizes, mas sem poder sê-lo. Pois nem todos querem viver com retidão, e é só com essa boa vontade que se têm direito à vida feliz. (Agostinho, 1995, pág. 62/63)

O mal vem da paixão interior, o homem que pensa em abusar da mulher do próximo peca pela simples intenção em fazê-lo, independentemente de ter de fato realizado ou de ter sido impedido de fazê-lo. É a vontade do homem livre para cometer o mal, está no poder da razão fazer com que ele não cometa e este é o seu mérito perante Deus de que será recompensado.

Portanto, não há nenhuma outra realidade que torne a mente cúmplice da paixão a não ser a sua própria vontade e o livre arbítrio. (Agostinho, 1995, pág. 52)

O que prova que o homem é o dono da sua vontade? Quem pode afirmar que suas escolhas não são ilusórias e age então o homem a morder sempre a mesma isca da qual ele não pode consegue recusar. De onde vem essa vontade capaz de escolher o destino que for ao homem seja ele coerente ou não com o que ele deveria desejar? Para Agostinho a razão é mais forte do que a paixão, prova é que os homens sendo inferiores em muitos aspectos físicos aos animais ainda assim conseguem dominá-los. Aos animais não faltam os desejos sensíveis presentes ao homem, mas falta a eles a faculdade da razão, o homem os consegue ser dominante por que sabe apelar para os desejos corporais dos animais aos quais eles não conseguem resistir. É a mente, então, mais forte do que a paixão. Deus não força a mente a submeter- 
se às paixões, portanto é livre a razão para escolher segui-las ou a pretender um bem maior.

\begin{abstract}
Julgaremos que para a mente poderá ser um pequeno castigo ser dominada pela paixão e despojada das riquezas da virtude, torna-se pobre e desgraçada, ser puxada por ela em todos os sentidos? Às vezes, aprovar a falsidade em vez da verdade; outras vezes, parecer mesmo defender o erro; outras condenar o que até então aprova; e não obstante, precipitar-se em novos erros? Numa hora, suspender o seu julgamento até temer as razões que a esclareceriam; noutra, desesperar de jamais encontrar a verdade e mergulhar totalmente nas trevas da loucura. Amanhã, esforçar-se por abrir-se na direção da luz da inteligência, para de novo recair extenuada. Ao mesmo tempo, o império das paixões ao lhe impor sua tirania, perturba todo o seu espírito e ávida desse homem, pela variedade e oposição de mil tempestades, que tem de enfrentar. (Agostinho, 1995, pág. 52/53)
\end{abstract}

E também para Agostinho está no poder da vontade de cada um escolher o que aceita ou rejeita, mas não está no poder de ninguém aceitar ou rejeitar. "Ninguém pode determinar qual o objeto cuja vista o impressionará" (Agostinho, 1995, pág. 237). O pecado do homem e do demônio veio do orgulho ao quererem se elevar e encontrar o gozo na própria independência. De todas as vantagens que Deus ofereceu a Adão ele preferiu a independência, o orgulho foi o seu pecado. O demônio acrescentou a inveja, a mais odiosa, até persuadir ao homem esse mesmo orgulho, em razão do qual ele tinha consciência de ter sido condenado. Estava no poder do homem resistir à tentação, mas ele não o fez. O seu desejo de saber o que Deus sabia foi mais forte do que a sua obediência a ele. Mas aconteceu que a punição infligida ao homem foi destinada a corrigi-lo, mais do que a dar ao mesmo a morte. Etienne Gilson explica muito bem estas proposições:

...torna-se contraditório imaginar uma causa positiva, tal como Deus, na origem do movimento de aversão pelo qual a vontade livre se desvia dele. Sem dúvida, Deus criou a vontade mestra de si mesma e capaz de se apegar ao soberano bem ou de se desviar deste; mas se a vontade assim criada poderia se desligar de Deus, ela não deveria; sua queda, uma vez que ocorreu, não foi à queda natural e fatal de uma pedra que cai, mas a queda livre de uma vontade que se abandona. Simples defeito falta de ordem e, por 
conseqüência, falta de ser, o movimento da queda original não tem outra origem a não ser o nada, ou seja, o não ser. (Etienne Gilson, 2007, pág.279)

O julgamento de Deus para com os homens não retira deles a sua liberdade, as suas recompensas e punições existem justamente por que é concedida ao homem uma livre escolha. Ainda que haja um caminho certo a seguir, existem outras tentações às quais o homem pode sucumbir. O prêmio é merecido ao homem que se sacrifica para agir conforme os desígnios de Deus e é justo que Deus que fez o homem também o recompense por louvá-lo e o castigue por sua ingratidão.

\section{Interpretação da Liberdade em Agostinho}

A liberdade da vontade se corporifica no asno de Buridan, atribuída ao lógico Johannes Buridanus. Um asno esfomeado se encontra no meio de um caminho atraído por dois fenos eqüidistantes. De acordo com a tradição determinista da vontade o asno morreria de fome já que se sentiria atraído em igual medida pelos dois lados. (Jürgen Habermas, 2005, pág. 207) O que acontece quando alguém é forçado a escolher entre dois objetos de igual valor? Se não há uma vontade livre, apenas uma vontade determinada por uma condição externa, por que alguém escolheria $x$ ao invés de $y$ ? Supondo que $o$ asno escolha o lado esquerdo, poderíamos determinar que a causa disso fosse um simples hábito, criado na própria experiência do asno que sempre viu o feno no lado esquerdo. Mas isso também seria uma escolha, o asno escolheria seguir o seu hábito, ele pesaria na balança da sua escolha algo que não tem 
qualquer relação com seu objetivo: o de matar a fome. A vontade é livre justamente porque pode agir em sentido contrário às suas paixões naturais.

Por falta de conhecimento, pela falta de deliberação ou pelo mau desempenho em julgar, o homem pode escolher qualquer um dos caminhos. $O$ que Agostinho prega é que mesmo havendo um caminho certo e indubitável para a felicidade do homem ainda assim ele pode ir por outro caminho, pois tem a posse do livre-arbítrio que está intrínseco no próprio poder racional ao qual foi concedido ao homem. A razão pressupõe a liberdade da nossa vontade, sem esse poder de fazer um livre juízo para escolher inclusive o que é prejudicial ao próprio agente, ele não pode ser considerado um ser racional. Um autômato não pode ser considerado inteligente, ele não possui faculdade alguma, age sempre determinado por um desencadeamento lógico da busca pelas suas necessidades pré-ordenadas, totalmente previsíveis e sem nenhum mérito por suas decisões. O mérito do homem em ser sábio é o de poder seguir sempre fazendo a melhor escolha.

Todo homem possuí em si uma vontade que pode ser resumida assim na vontade de ser feliz, deliberar livremente sobre os caminhos que o levarão à felicidade está no poder da vontade livre. A vontade do homem está então em meio a uma tormenta de desejos, ela é um barco em meio a uma tempestade sendo virado para lá e para cá pelas várias correntezas, é livre o comandante do barco de seguir ou não conforme a maré ou os ventos em busca do seu destino.

O que tiramos de Agostinho é a segurança de que ao menos a nossa vontade é livre, mas a experiência comum mostra como não é imediato o 
querer e o poder, assim como não está livre o poder do homem para fazer que as coisas aconteçam conforme a sua vontade, pois a natureza segue o seu curo independentemente do homem como se ele não existisse e vez por outra se vê o homem frustrado em seu desejo de felicidade por causas exteriores à sua vontade. Têm-se, então, uma liberdade para querer, mas em que medida nós somos livres para agir?

\section{RENÉ DescaRTES:}

\section{A LIBERDADE DE ESCOLHA}

\section{A Determinação da Vontade}

Ainda que a vontade do homem seja livre se ele não tem o poder de expressar sua vontade por meio de suas ações, sua liberdade não se exprime no mundo exterior. É necessário que nosso corpo seja determinado por nossa vontade, pois se existe algo fora de nossa mente que desencadeia as nossas ações a vontade é impotente mesmo dentro de nós mesmos. Sobre esse problema voltemos ao pensamento de Agostinho:

Evódio: O seguinte: uma vez que a vontade nos foi dada de tal forma que essa inclinação aos bens inferiores lhe seja natural, então ela tem necessariamente de se voltar para tais bens. Ora, não se pode descobrir culpa alguma onde dominam a necessidade e a natureza. (Agostinho, 1995, pág.147)

Em Agostinho vemos uma semelhança com o pensamento de Descartes ao encontrar dentro do próprio homem a verdade eterna a qual nossa mente contingente e mutável não poderia produzir, a prova da existência de Deus vem justamente dessa certeza interior. E é Descartes quem defende a 
possibilidade de submissão do corpo às vontades da alma que é a condição para reprimirmos o movimento natural do corpo aos bens inferiores.

Mas a vontade é, por natureza, de tal modo livre que nunca pode ser compelida; e, das duas espécies de pensamentos que se distingui na alma, das quais uns são suas ações, isto é, suas vontades, e outros as suas paixões, tomando-se esta palavra em sua significação mais geral, que compreende todas as espécies de percepção, os primeiros estão absolutamente em seu poder e só indiretamente o corpo pode modificá-los, assim como, ao contrário, os últimos dependem absolutamente das ações que os produzem, e a alma só pode modificá-los indiretamente, exceto quando ela própria é a causa. (Descartes, 1973, pág. 243)

Para Descartes alma está no controle direto das nossas vontades e o corpo é apenas um receptor das emoções. E toda ação da alma faz com que o corpo produza o efeito relacionado com a nossa vontade. Descartes achava que a alma tinha um lugar específico no nosso corpo: a glândula pineal. Ele pensava também ser a alma algo não sensitivo, seria ela equivalente à mente, ou melhor, seria a alma a cede da vontade. É a vontade que move a glândula que por sua vez move os músculos do corpo. Mas reconhece Descartes que nem sempre é a vontade que é responsável pelos movimentos da glândula.

Assim, por exemplo, se se quer dispor os olhos para olhar um objeto muito distanciado, essa vontade faz com que a pupila se dilate; e se se quer dispô-los a olhar um objeto muito próximo, essa vontade faz com que a pupila se contraia; mas se se pensa apenas em alargar a pupila, em vão teremos tal vontade, pois nem por isso conseguiremos alargá-la. (Descartes, 1973, pág. 244)

Nós não podemos por nossa vontade mover todas as partes do nosso corpo livremente, mas é certo que temos mais êxito movendo-as de acordo com nossos propósitos do que tentando movê-las nos concentrando nesses mesmos movimentos. Assim também são as nossas paixões que não podendo ser diretamente excitadas nem suprimidas pela ação de nossa vontade, mas podem ser pela representação das coisas que queremos ter. 
considerar as razões, os objetos ou os exemplos que persuadem de que o perigo não é grande; de que há sempre mais segurança na defesa do que na fuga; de que teremos a glória e a alegria de havermos vencido, ao passo que não podemos esperar da fuga senão o pesar e a vergonha de termos fugido e coisas semelhantes. (Descartes, 1973, pág. 244)

Também explica Descartes a razão para que a alma não disponha inteiramente de suas paixões. Ela por si mesma não consegue imediatamente suprimir a emoção e, por conseguinte não supre às ações que acompanham a essas emoções. As emoções mais fortes são como um fogo que queima a mão que não se pode deixar de sentir ou um trovão que não se pode deixar de ouvir, coisa que podemos fazer com as pequenas emoções do mesmo jeito que podemos deixar de prestar atenção em um ruído ou de sentir uma pequena brasa.

O máximo que pode fazer a vontade, enquanto esta emoção está em vigor, é não consentir em seus efeitos e reter muitos dos movimentos aos quais ela dispõe o corpo. Por exemplo, se a cólera faz levantar a mão para bater, a vontade pode comumente retê-la; se o medo incita as pessoas a fugir, a vontade pode detê-las, e assim por diante. (Descartes, 1973, pág. 245)

Descartes defende que há um combate unicamente entre a vontade da alma e as necessidades do corpo que ele denomina por espíritos (corpos muito pequenos que se movimentam muito depressa no corpo e o movimentam). Tudo em nós que repugna a nossa razão não vem de outro lugar a não ser das funções do corpo. É o corpo que impele na alma o desejo por alguma coisa que a vontade pode ou não repugnar. Não tendo a alma o poder de imprimir nela mesma as paixões a alma pondera as diversas paixões impressas pelo corpo chegando mesmo a querer e não querer uma coisa ao mesmo tempo. Aqueles que têm o poder de por sua vontade suspender as paixões e sustar os movimentos do corpo são aqueles que têm as almas mais fortes. Apenas os juízos firmes e determinados sobre o conhecimento do bem e do mal fazem a 
alma conduzir as ações de sua vida e é infeliz e escrava a alma que não decide seguir certos juízos, mas se deixa arrastar continuamente pelas paixões presentes, as quais a puxam ora para um lado e ora para o outro. A força da alma, diz Descartes, não basta para bem agirmos é necessário também que se faça corretamente o juízo adequado, coisa que a maioria não consegue fazer.

\section{A Liberdade em Descartes}

Descartes não vê a necessidade de se provar a liberdade. Para ele é a liberdade algo evidente, algo do qual podemos sentir e que é a maior prova da existência de Deus. Nas suas respostas às quintas objeções diz o seguinte a respeito da liberdade:

Ainda que negueis, em seguida, que a indiferença da vontade seja de si mui manifesta, não quero, entretanto tentar proválo a vós, pois isto é tal que cada um deve senti-lo e experimentá-lo em si mesmo mais do que persuadir-se disso pela razão. (Descartes, 1973, pág. 205)

Um exemplo da concepção de liberdade apresentada é o cogito. O estabelecimento do elo entre duas partes do argumento e o que me impele a afirmá-lo é uma determinação interior proporcionada pela clareza do entendimento. O meu livre-arbítrio é o que me permite negar aquilo que me é evidente e pensar nas possibilidades que eu mesmo sei que não estão corretas. Se ao homem não fosse concedida a faculdade de livre escolha, de modo que a ele fosse impossível errar, ele não seria inteiramente livre, agiria assim sempre em direção a um caminho já traçado.

De onde nascem então os meus erros? A saber, só do fato de que, sendo a vontade muito mais ampla e mais extensa do que o entendimento, não a contenho nos mesmos limites, mas a estendo também às coisas que não entendo; sendo por si indiferente a elas, 
ela se desencaminha com muita facilidade e escolhe o mal pelo bem, ou o falso pelo verdadeiro. O que faz com que me engane e peque. (Descartes, 2005, pág. 90/91)

É o fato de o livre-arbítrio ser capaz de rejeitar ou aceitar que somos abertos aos elogios ou à censura ao mérito ou ao demérito. Para Descartes, então, "o voluntarismo e a liberdade são uma e a mesma coisa", e o uso adequado da liberdade é nos conduzir a agir apenas a partir de concepções claras e distintas (J.B.Schneewind, 2001, PÁG. 219). E da mesma forma que àquele que julga os olhos ser a parte mais bonita do corpo, não acharia bonito um homem que tivesse centenas de olhos espalhados no corpo, o fato de ser o acerto uma forma mais perfeita não seria o mundo mais perfeito se todos acertassem sempre. Os erros são conseqüência dessa potência de eleger como diz Descartes ao se referir ao livre-arbítrio.

Nas meditações reconhece Descartes em si mesmo uma potência de julgar e que Deus Ihe deu um livre arbítrio e uma vontade extensa que não está encerrada em nenhum limite. Já nas respostas às quintas objeções sobre a meditação quarta Descartes responde o seguinte a cerca da liberdade:

Não seja, portanto livre, se a tanto voz apraz; quanto a mim gozarei de minha liberdade, pois não só a sinto em mim mesmo como também vejo que, tendo o desígnio de combatê-la, em lugar de oporIhe boas e sólidas razões, vós vos contentais simplesmente em negála. E talvez eu encontrasse mais crédito no espírito dos outros afirmando o que experimentei, e que cada um pode experimentar em si mesmo, do que vós, que negais uma coisa pelo simples fato de que jamais talvez a haveis experimentado. (Descartes, 1973, pág. 206)

E o que alguns chamariam de moral provisória em Descartes não é outra coisa senão a máxima expressão da nossa liberdade de escolha. Devemos optar por um caminho, pois a nossa felicidade não pode esperar, sendo que apenas Deus pode conhecer onde irão dar todos os caminhos, e é 
essa a razão de cada homem escolher dentre todos os caminhos, o melhor, ainda que jamais tenha a certeza absoluta da precisão de sua decisão.

Minha segunda máxima era ser o mais firme e resoluto que pudesse ser em minhas ações, e não seguir com menos constância as opiniões mais duvidosas, uma vez que por elas me tivesse determinado, do que as seguiria se fossem muito seguras. Nisto imitando os viajantes que, achando-se perdidos em alguma floresta, não devem ficar perambulando de um lado para outro, e menos ainda ficar parados num lugar, mas andar sempre o mais reto que puderem na mesma direção, e não a modificar por razões insignificantes, mesmo que talvez, no início, tenha sido apenas o acaso que thes tenha determinado a escolha: pois, desse modo, se não vão exatamente onde desejam, ao menos acabarão chegando a algum lugar, onde verossimilmente estarão melhores do que no meio da floresta. E assim, como as ações da vida freqüentemente não suportam nenhum adiamento, é uma verdade muito certa que, quando não está em nosso poder discernir as opiniões mais verdadeiras, devemos seguir as mais prováveis; e ainda que não notemos mais probabilidades numas que nas outras, mesmo assim devemos nos determinar por algumas, e considerá-las depois, não mais como duvidosas, no que diz respeito à prática, mas como muito verdadeiras e muito certas, porque a razão que a isso nos determinou o é. (Descartes, 2003, pág. 29/30)

\section{Interpretação da Liberdade em Descartes}

Jürgen Habermas no seu livro: Entre Naturalismo e Religião cita vários autores contemporâneos que sustentam o não livre arbítrio da vontade.

"Pouco importa o resultado da avaliação racional: ele está submetido à decisão última (!) do sistema límbico, porquanto ele tem de ser emocionalmente aceitável [...] Diferentemente do que é afirmado pela psicologia do cotidiano, não são os argumentos lógicos enquanto tal que nos estimulam ao agir racional." (Jürgen Habermas, 2005, pág. 174)

Habermas cita os experimentos de Benjamin Libet que observara em laboratório que há uma considerável diferença de tempo entre o agir e o decidir agir e que este último não vem primeiro. Criar-se um potencial de disposição para agir, antes que a própria pessoa decida a agir. Como se o agente tivesse já uma pré-disposição a agir dessa ou daquela maneira antes mesmo de que a 
situação se apresente a ele, algo que se deveria a seu histórico pessoal ou a sua pré-condição emocional.

"O que o agente realiza intencionalmente é precisamente aquilo que se coloca diante de sua liberdade e para cuja execução ele possui argumentos adequados". Somente uma vontade refletida é livre. (Jürgen Habermas, 2005, pág.175)

Quando nessa citação de Davidson, Habermas define a liberdade da vontade como dependente de um juízo antecipado limita a ação a uma ponderação interna entre os caminhos e alternativas as que tornariam qualquer potência do indivíduo de agir impossível. Para Descartes a irresolução é um vício da alma. Se o homem sempre devesse fazer um juízo complexo a cerca de cada decisão que tomar nunca fará coisa alguma. Isso não excluiu a liberdade da vontade, a decisão de agir é programada por nossa vontade ainda que outra seja a ocasião para agir. Como o viajante que decide seguir por um caminho, suas ações subseqüentes são fruto daquela primeira decisão, pois ao seguir em linha reta em uma direção qualquer o viajante chegará a algum lugar o que jamais aconteceria se ele tivesse que considerar sempre todas as variáveis antes de tomar uma decisão.

Descartes encontrou em um mecanicismo do corpo a própria expressão de nossa liberdade, pois ao supor ser o corpo do homem uma máquina provida de uma vontade, colocou em nosso poder fazer valer o nosso desejo. Em meio à tormenta dos diversos sentimentos que afligem o homem a vontade é a força capaz de medir todas as correntes emocionais e decidir-se por um caminho. É essa a essência da nossa liberdade de escolha, pois de que serviria a livre vontade se ela não pudesse se manifestar por causa dos nossos desejos passageiros e puramente físicos? 
Depois de mostrar-se que o livre-arbítrio da vontade é uma précondição da nossa existência como indivíduos, mostrou-se com Descartes que a vontade nunca é submissa às necessidades do corpo por ser ela mesma capaz por meio do uso da razão de fazer o julgamento adequado balanceando os diversos sentimentos que estamos sujeitos e decidindo livremente utilizando o poder da razão. Mas mesmo com Descartes a liberdade ainda encontra uma barreira: Deus. Que poder tem o homem ainda que de posse da liberdade de escolher de agir com vista ao seu próprio desejo? Se tanto em Agostinho como em Descartes somos persuadidos a crer que a suma perfeição está quando não desejamos nada a não ser a realização da vontade de Deus, quando são livres os nossos desejos?

\section{BARUCH DE ESPINOSA:}

\section{A LIBERDADE DO DESEJO}

\section{O Determinismo em Espinosa}

Na sua obra "Ética Demonstrada à maneira dos Geômetras", Espinosa expõe um mundo de determinismo e não de desígnio, um mundo sem fins absolutos, onde Deus está acima dos nossos pequenos bens e pequenos males. "O mecanicismo que Descartes via somente na matéria e no corpo, Spinoza vê também em Deus e na mente" (Will Durant, 1996, pág.175). Nada então no universo aconteceria de maneira diversa do que já acontece, o futuro seria assim um resultado determinado e necessário da condição presente do universo. 
Se alguém quiser negar isso, não daria trabalho demonstrar-Ihe seu erro. Com efeito, se ele considerar a Natureza e como ela depende de Deus, não descobrirá nas coisas nada de contingente, isto é, que tomado do lado da coisa possa ou não existir, ou, para falar como se diz vulgarmente, que seja realmente contingente o que se vê facilmente quando se considera que a mesma força é requerida para criar e para conservar uma coisa. (Spinoza, 1973, pág. 16)

Spinoza não vê na Natureza nada que possa ser probabilístico, tudo tem uma causa necessária que tem sua origem em Deus. Não como os atomistas que viam tudo no mundo como uma causa material, Spinoza vê a predestinação de Deus na propriedade fundamental das substâncias. Como se estivesse no "programa" de cada substância o fim ao qual Deus as designou.

No que se refere à liberdade da vontade humana, que dissemos ser livre, também ela se conserva pelo concurso de Deus, e nenhum homem quer ou faz a não ser aquilo que Deus decretou pela eternidade que queria ou faria. Como isso é possível, mantida a liberdade humana, é coisa que ultrapassa nossa compreensão. (Spinoza, 1973, pág. 17)

Assim como o DNA de uma célula ou o programa de um computador, a Natureza tem na sua essência algo que se segue necessariamente, nada fica ao acaso, pois até mesmo o DNA ou a programação da máquina pode falhar, mas Deus não falha. $E$ isso parece um pouco com o que Agostinho prega no livre arbítrio:

Evódio: Assim sendo, sinto-me sumamente preocupado com uma questão: como pode ser que, pelo fato de Deus conhecer antecipadamente todas as coisas futuras, não nos venhamos a pecar, sem que isso seja necessariamente? (Agostinho, 1995, pág.152)

Agostinho, então responde que a presciência divina não anula a nossa vontade, pois se Deus prevê que o homem será feliz, não é contra a vontade do homem que essa felicidade se realiza. Se fosse então necessário que o homem queira algo determinado de onde viria então esse querer? Como chamar isso de vontade? Quando queremos se a nossa vontade nos faltasse não o quereríamos de fato. Para Agostinho então nós queremos livremente 
aquilo que queremos, mas Deus tem presciência desse ato livre, Deus previu esse poder. É essa a diferença entre Agostinho e Spinoza. Para Spinoza Deus fez o universo em um único ato de vontade nada existindo antes dessa vontade, nem Deus. Por isso em Spinoza Deus não apenas sabe tudo o que vai acontecer ele fez tudo com um intuito já determinado.

E qual é então esse intuito? Para Spinoza nenhum. Deus não age com nenhum objetivo.

$\mathrm{Na}$ concepção de Spinoza, Deus não age com nenhum objetivo. Spinoza não está simplesmente dizendo, como Descartes, que não podemos conhecer os propósitos de Deus. Em vez disso, está declarando que o mundo que é Deus-ou-Natureza expressa Deus plenamente, ainda que seja desprovido de valor ou propósito. Embora seja um todo logicamente unificado, não obstante carece de significado ou de objetivo. Como um turbilhão de átomos epicurista. $\mathrm{O}$ mundo como provém de Deus não contém nada do que chamamos de "bem e mal, mérito e pecado, elogio e censura, ordem e confusão, beleza e feiúra". (J.B.Schneewind, 2001, pág. 249)

E em meio a esse supremo determinismo causal de Spinoza vemos pelo menos um espaço para a liberdade ao afirmar que as regras necessárias de Deus não são seguidas de nenhuma causa necessária, foi assim pelo ato livre de Deus.

\section{A Liberdade em Spinoza}

Se no universo não há nada de contingente para Spinoza, onde estaria a liberdade? No próprio agente. O que Spinoza acrescenta aos argumentos em favor da liberdade é colocar o bem do homem não na vida eterna, mas na vida do homem na Terra e voltar esse bem ao homem mesmo, tudo que emana dos homens tem um fim neles mesmos. Nas primeiras partes de sua ética Spinoza já diz: 
O desejo é a própria essência do homem, isto é, um esforço pelo qual o homem se esforça por perseverar no seu ser. (Spinoza, 1973, pág. 244)

Princípio que nos leva a retroceder ao que já demonstramos com Agostinho e Descartes que o homem não é como a pedra que cai pela força da gravidade, pois o homem tem a potência de resistir a essa queda natural. Mas para Spinoza o homem é uma pedra achando que é ela mesma quem determina a trajetória e escolhe o lugar e a hora da sua queda (Will Durant, 1996, pág. 179). E não como em Agostinho onde é o homem quem decide pelos bens inferiores, ou seja, para Agostinho e Descartes o desejo não participa da idéia de homem.

\footnotetext{
Proposição VI: Toda coisa se esforça, enquanto está em si, por perseverar em seu ser.

Proposição VII: O esforço pelo qual toda coisa tende a perseverar no seu ser é senão a essência atual dessa coisa. (Spinoza, 1973, pág. 188/189)
}

Para Spinoza como não está contida na coisa nada que a destrua e como a coisa opõe-se a tudo que poderia lhe suprimir sua existência, concluise que é da própria natureza da coisa se preservar. Então o homem não é livre, pois sua vontade não pode querer aquilo que vai contra a sua própria natureza.

Este esforço, enquanto se refere apenas à alma, chama-se vontade; mas, quando se refere ao mesmo tempo à alma e ao corpo, chama-se apetite. $O$ apetite não é senão a própria essência do homem, da natureza da qual se segue necessariamente o que serve para a sua conservação; e o homem é, assim, determinado a fazer essas coisas. (Spinoza, 1973, pág. 190)

Então não é decisão da vontade escolher ou não seguir esse apetite, ela não pode agir de forma contrária. Para Agostinho toda a natureza que não se fixe no bem supremo é digna de ser censurada e o Bem supremo e imutável é justamente o bem de seu criador. Mas em Spinoza o bem do homem está somente em procurar aquilo que lhe é útil. 
É, portanto, evidente, em virtude de todas estas coisas que nós não nos esforçamos por fazer uma coisa que não queremos, não apetecemos nem desejamos qualquer coisa porque consideramo-la boa; mas, ao contrário, julgamos que uma coisa é boa porque tendemos para ela, porque a queremos, apetecemo-la e desejamo-la. (Spinoza, 1973, pág. 190)

Spinoza coloca a vontade como parte da compreensão do termo homem, sem esse apetite o homem não é homem. Nisso ele apresenta a liberdade sobre outro ponto de vista.

Ora o desejo é a própria natureza ou essência de cada indivíduo; portanto, o desejo de um difere do desejo de outro tanto como a natureza ou essência de um difere da essência do outro. (Spinoza, 1973, pág. 217)

Portanto, o homem não é mais livre quando não deseja como pregavam os estóicos ou os budistas. Assim como uma planta que conseguisse viver sem clorofila não seria uma planta mais livre, ela apenas deixaria de ser planta. Essa vontade de se preservar ou de gozar com aquilo que a alma ou a idéia da qual constituí no indivíduo a sua própria natureza é algo intrínseco a sua própria essência. Sem esse apetite o homem não é homem, como a planta não é planta se não tentar cravar suas raízes na terra para buscar água. E nisto temos a liberdade em Spinoza, pois se não temos a liberdade causal, temos a liberdade do nosso desejo que com Agostinho e Descartes nunca poderíamos ter chegado. Pois a vida beata é a vida subserviente a Deus, com Spinoza temos a liberdade de encontrarmos o nosso próprio gozo conveniente a nós mesmos.

Enfim, segue-se da proposição precedente que não é pequena a diferença entre o gozo que sente, por exemplo, o ébrio, e o gozo atingido pelo filosofo, o que quis observar aqui de passagem. (Spinoza, 1973, pág. 219)

Todavia Spinoza não discorda de Agostinho ao encontrar a servidão humana na impotência para governar e refrear as afecções. A diferença está em conceber a virtude como um bem em si mesmo e não como um meio de 
alcançar um bem maior e eterno. E por isso na parte $V$ da Ética Spinoza fala da liberdade:

\begin{abstract}
Parece ser outra a persuasão comum do vulgo. Com efeito, a maior parte dos homens parece acreditar que é livre na medida em que lhe é permitido obedecer às suas paixões; e que renunciam ao seu direito na medida em que são obrigados a viver segundo as prescrições da lei divina. Julgam, pois, que a piedade e a religião, e de maneira geral tudo o que se refere à força da alma, são fardos, que esperam depor depois da morte, para receber o preço de sua escravidão, a saber: da piedade e da religião. E não é só por esta esperança, mas ainda e, sobretudo pelo medo de serem punidos depois da morte por cruéis suplícios, que eles são levados a viver segundo as prescrições da lei divina, tanto quanto o permitirem a ligeireza e inconstância do seu espírito. (Spinoza, 1973, pág. 306)
\end{abstract}

A liberdade de Spinoza consiste apenas nisso nessa consciência de si mesmo, de Deus e das coisas. Para ele a virtude não é premiada com a felicidade, mas é a própria felicidade que quando é gozada da o poder ao homem de refrear as paixões. Para Spinoza são a liberdade e a beatitude da alma as mesmas coisas.

\title{
III. Interpretação da liberdade em Spinoza
}

Concluímos, por conseguinte que Spinoza não nega a liberdade da vontade de Agostinho, nem mesmo ao argumentar contra Descartes. O que ele faz é identificar a vontade com o intelecto e assim coloca a liberdade como o poder de afirmar ou negar certas idéias. Ele critica Descartes no que ele afirma ser o homem inteiramente capaz de dominar suas paixões e vai contra a tradição filosófica antiga e medieval que é a felicidade em si que conduz a virtude e não a virtude a felicidade. Mas o que podemos tirar de novo sobre a liberdade em um sistema determinista como o de Spinoza? 
A questão se coloca do seguinte modo: É livre um homem que entrega o seu relógio a outro que o ameaça com uma arma? O homem tem em seu poder a opção de não entregar, mas se fizer isso ele morre. Então o homem pode escolher resistir ao bandido e morrer ou entregar um bem de pouco valor e continuar vivo. A que chamaríamos esse tipo de liberdade? Fica explícito que quando coagimos alguém não tiramos dele seu livre-arbítrio, o que fazemos e reduzir suas possibilidades de escolha aponto de dar a ele uma opção que ele provavelmente não aceitará. Como um pai ao castigar um filho, ou como Deus a punir os homens. Apesar de Spinoza não negar o julgamento final, ele constrói argumentos que nos levam a crer que devemos agir com fins às coisas em si mesmas e não com a esperança de uma recompensa ou com medo de um castigo. Liberta-nos assim da coação da arma, ainda que diga que devemos dar o relógio ao bandido mesmo que ele não nos ameace.

Se retirarmos de Spinoza a conotação religiosa, resta então a definição do desejo como inerente a essência do homem. Pois de que adiantaria uma vontade livre sem um fim determinado, por que o homem agiria dessa ou daquela maneira sem algo dentro dele que desse sentido ao que ele faz. Para Agostinho e Descartes esse fim último seria Deus, tudo que emana do homem só teria sentido se fosse em direção a salvação eterna, ou aceitamos isso, ou seremos punidos eternamente. Não há muita opção para o nosso livre arbítrio uma vez que nosso objetivo já está traçado. Mas se está na própria essência do homem desejar então tem o homem um fim independente de causas exteriores e nisso ele é livre para buscar dentro de si mesmo seu próprio caminho. O que não anula Deus, mas coloca o homem no centro das ações humanas e coloca o indivíduo no centro das ações sociais. 
Vemos então em meio ao determinismo causal de Spinoza o conatus sese preservandi que dá ao homem a posse do leme que dirige a sua vida. Mas se a vontade é livre, a escolha é livre, o desejo é livre, o que ainda falta para a liberdade se realizar plenamente? Precisa-se provar que a vida não é um filme com um roteiro conhecido apenas pelo criador ou que não é um trem rumo a um destino já traçado pelos próprios trilhos, precisamos provar que há no mundo mais de uma possibilidade.

\section{GOTTFRIED WILHELM LEIBNIZ:}

\section{A LIBERDADE DE PODER}

I. O Determinismo em Leibniz

Leibniz crê em no mundo de forma extremamente otimista, para ele não faz sentido Deus ser onipotente e onisciente sem ter criado o mundo da melhor forma possível. O otimismo notório de Leibniz e sua tese de que esse é o melhor dos mundos possíveis vem da sua rejeição ao voluntarismo de Descartes. O voluntarismo defende a liberdade de Deus em decidir de forma arbitrária e indiferente as suas leis de certo e errado.

A derrota do voluntarismo é, para Leibniz, o ponto crucial na demonstração de que a ordem cósmica e racional e, por isso, tem um apelo normativo igual para todos. Descartes não tenta diminuir as conseqüências chocante do seu voluntarismo extremo, segundo o qual a vontade de Deus deve parecer totalmente arbitrária a partir do nosso ponto de vista, e até mesmo aquilo que para nós é autoevidente racional e justo só o é porque Deus tornou nossas mentes incapazes de pensar de outra maneira. (J.B.Schneewind, 2001, pág. 271) 
Spinoza, como Descartes também não explica por que as leis de Deus são assim e não de outro jeito, para ele Deus fez do jeito que fez por que quis fazer e não vê ele nenhum outro motivo. Agostinho também reconhece que Deus podia se tivesse querido que as coisas se procedessem de forma totalmente diferente, pois a vontade de Deus é livre.

\begin{abstract}
A tirania, o despotismo, a excentricidade casual e o tratamento dos seres humanos como "vermes", convenientemente esmagados enquanto se anda (Theodicy, p. 58, 237, 402-3)—são estes que Leibniz sempre associa com a divindade voluntarista, e usa esses termos para nos convencer de que não podemos aceitar essa descrição. (J.B.Schneewind, 2001, pág. 272)
\end{abstract}

Então o determinismo em Leibniz se manifesta na descrição de Deus, por definir Deus com o propósito de fazer sempre o bem e de que esse é o melhor dos mundos possíveis. Desta forma não há nenhuma possibilidade de imaginar uma mudança no mundo ou mesmo outra realidade possível.

Deus não é menos livre por não agir de forma arbitrária, como não somos mais livres por serem as coisas sempre do jeito que queremos. $O$ mundo segue suas leis necessárias e Deus não procede de modo arbitrário por que ele tem na sua própria essência, na sua definição ser perfeitamente bom. Leibniz dá nova perspectiva à idéia de liberdade ao reconhecer que ela não significa arbitrariedade completa, isso não apenas é impossível, mas acabaria com a própria liberdade. A suprema liberdade seria agir com perfeição segundo a razão soberana. Então o que se pode chamar de determinismo em Leibniz é a concepção de que esse é fatalmente o melhor dos mundos e de que Deus não o poderia tê-lo feito de maneira diferente. Mas isso não anula a liberdade por que entende Leibniz que liberdade não significa indeterminação, o problema da liberdade só faz sentido ao se falar no poder de se fazer algo conforme a nossa vontade. Ser livre não é agir sem impedimento. 
Filaleto: Convém também ponderar que ninguém ainda se lembrou de considerar agente livre uma bola, quer ela esteja em movimento após ter sido impulsionada por uma raquete, quer ela esteja em repouso. Eis por que não concebemos que uma bola pense, nem que tenha qualquer volição que a faça preferir 0 movimento ao repouso.

Teófilo: Se livre fosse aquilo que age sem impedimento, a bola, desde que estivesse em movimento em um horizonte unido, seria um agente livre. Ocorre que Aristóteles já observou com muita razão que para denominar as ações livres, exijamos que elas sejam não só espontâneas, mas deliberadas. (Leibniz, 1999, pág. 158)

\section{A Liberdade em Leibniz}

Depois de demonstrar que esse é o melhor dos mundos possíveis, Leibniz precisaria ainda encontrar uma justificativa para que as pessoas se movessem a melhorar a si mesmas e a melhorar o mundo. Sua solução em certo aspecto lembra a de Santo Agostinho ao manter o livre-arbítrio mesmo com a presciência de Deus. A liberdade de ação existe dentro do domínio do moralmente necessário. Deus sempre age livremente; nós podemos ou não agir livremente.

\footnotetext{
Filaleto: Encontramos em nós mesmos a potência de começar ou não começar, de continuar ou de terminar várias ações da nossa alma e vários movimentos do nosso corpo, e isso simplesmente por um pensamento ou uma opção do nosso espírito, que determina e comanda, por assim dizer, que tal ação particular seja praticada ou não. Esta potência que denominamos vontade. (Leibniz, 1999, pág. 156)
}

Leibniz concorda com Spinoza ao colocar o conatus como aquilo que precede à vontade. Assim as ações voluntárias internas ou externas do nosso espírito seguem esse conatus. Leibniz define o conatus como o esforço ou tendência para aquilo que consideramos bom e contra o que se acredita mal. Ele distinguiu a liberdade de querer e a liberdade de fazer, a liberdade de querer pode ser entendida de dois modos diferentes. No primeiro sentido como 
liberdade oposta à escravidão do espírito pelas paixões, tal como defendiam os estóicos e da qual se voltaram Agostinho, Descartes e Spinoza como vimos. Em outro sentido à liberdade de querer se refere àquilo que se opôs Spinoza, a liberdade de querermos que as razões ou impressões que o entendimento apresenta à vontade não a impeçam de ser contingente, que não lhe dêem uma necessidade absoluta e metafísica. A liberdade de fazer é aquela que temos em grau maior quanto maiores forem nossos meios, assim um prisioneiro ou um paralítico não são livres. Leibniz também distinguiu o necessário do determinado, os seres livres não agem de maneira indeterminada, como argumenta Spinoza, mas também não agem necessariamente, pois nada acontece sem razão. Deus escolhe livremente, contudo é determinado a escolher sempre o melhor.

Leibniz expõe o problema do determinismo colocado por Spinoza e a questão sobre a vontade ser livre:

Filaleto: Tornando o homem assim livre, quero dizer o seguinte: ao fazer com que a ação de querer dependa da sua vontade, é necessário que exista outra vontade ou faculdade de querer anterior para determinar os atos desta vontade, e outra para determinar os atos dessa vontade, e outra para determinar aquela, e assim até o infinito. Com efeito, onde quer que se pare, as ações da última vontade não podem ser livres. (Leibniz, 1999, pág. 164)

Leibniz acrescenta nova perspectiva ao determinismo de Spinoza:

Teófilo: Não queremos querer, mas queremos fazer, e se quiséssemos querer, quereríamos querer querer, é isso iria até o infinito. (Leibniz, 1999, pág. 164)

O homem então não tem a liberdade de querer querer, tem a liberdade de querer aquilo que é contrário ao que mais agrada somente para demonstrar a liberdade. Aquilo que determina a vontade a agir não é o bem maior, como se supõe comumente, mas antes alguma inquietação atual, e em geral a que é 
mais forte. O que se entende em Agostinho, Descartes e Spinoza é que o desejo do bem maior pode ser refreado por um desejo ou uma afecção presente e que a vontade fraca para Agostinho e Descartes escolhe em detrimento do bem eterno, Leibniz não abandona a busca do bem maior, mas enfatiza a atualidade do desejo como determinante da vontade. Como os algebristas por vezes se esquecem dos significados dos inúmeros símbolos que usam e passam a operá-los como se eles existissem por si mesmos, os homens desligam a prática atual dos seus corpos do conhecimento do bem que possuem sem uma fome e sede de justiça o conhecimento do bem e mal não chegará jamais a fazer com que sua vontade determine-se na busca do bem. Leibniz: "Ora, tal conhecimento não pode motivar-nos, requer-se algo de vivo para nos impulsionar" (Leibniz, 1999, pág. 167). Não são paixões como fala Descartes, antes são inquietações, parecido com o que Spinoza descreve, é do que Leibniz argumenta. O homem não é afetado de forma passiva por algo exterior, mas é ativado por elas interiormente. Mas Leibniz não pensa como Spinoza que a alma não pode controlar esses impulsos, nesse sentido pensa mais como Descartes.

Conheci um homem, considerável na igreja e no Estado, que devido às doenças tinha decidido fazer dieta; confessou-me, porém, que não pôde resistir ao odor das viandas que eram levadas aos outros ao passarem diante de sua residência. É sem dúvida uma fraqueza vergonhosa, mas assim são feitos os homens. Entretanto, se 0 espírito aproveitasse das suas vantagens, triunfaria brilhantemente. (Leibniz, 1999, pág. 168)

Leibniz também parece fazer uma síntese da liberdade defendida em Agostinho, Descartes e Spinoza:

Filaleto; Conclui-se, portanto que o entendimento sem liberdade não seria de nenhuma utilidade, e que a liberdade sem entendimento não significaria nada. Se uma pessoa pudesse ver o que lhe pode fazer bem ou mal, sem que fosse capaz de fazer um passo sequer para atingir o bem e evitar o mal, estaria em melhor 
situação pelo fato de ter o uso da vista? Seria até mais infeliz, pois desejaria inutilmente o bem e temeria o mal, que veria como inevitável. Por outra parte aquele que tem a liberdade de correr para cá ou para lá na escuridão, por que estaria em melhor situação do que aquele que é manobrado pelo vento? (Leibniz, 1999, pág. 186)

A liberdade é então uma forma de potência, uma potência ativa, pois não se refere à potência de sermos afetados, mas sim a potência de realizarmos algo seja o movimento seja o pensamento. Quando o agente põe seu próprio poder isso é uma potência ativa, mas quando o movimento e o pensamento recebem de fora a impressão pela qual a ação é comunicada temos uma potência passiva, ela é essa capacidade de receber essa impressão que faz com que a substância aja exclusivamente por essa capacidade. Toda a ação é um caminho para o prazer e toda paixão é um caminho para dor. Assim a determinação é útil ao homem e necessária do mesmo modo que a sensibilidade à razão na escolha do bem e do mal.

E se fôssemos determinados por outra coisa que pelo resultado que formamos no nosso espírito conformes tivéssemos julgado o bem ou mal de certa ação, não seríamos livres. (Leibniz, 1999, pág. 178)

Precisamos de uma determinação sobre nós mesmos para seguirmos àquilo que convém à nossa felicidade. Do mesmo modo a ciência e a teologia precisam buscar condições determinadas para que se possam conhecer a Natureza e Deus. Assim não necessitamos de uma metafísica espinosista para garantirmos a possibilidade da ciência, a liberdade e a ciência se mantêm com Leibniz. Como ele diz no seu discurso de metafísica:

Para resolvê-la solidamente, digo que há duas espécies de conexão ou consecução: é absolutamente necessária só aquela cujo contrário implique contradição (esta dedução dá-se nas verdades eternas, como as da geometria; a outra é só necessária ex hypothesi, ou, por assim dizer, por acidente, mas é contingente em si mesma, quando o contrário não implique contradição. E esta conexão fundase não apenas sobre as idéias absolutamente puras e sobre o simples entendimento de Deus, mas sobre os seus decretos livres e sobre a seqüência do universo. (Leibniz, 1974, pág. 86) 
Assim o certo e o necessário são coisas diferentes, é certo que Deus fez o melhor dos mundos possíveis, porém ele não $\circ$ fez assim necessariamente. Havia outras possibilidades que não entrariam em contradição com aquilo que Deus pode fazer, mas que é certo que ele escolheu essa e não outra possibilidade. Não existe esse fatalismo absoluto como descreveu Espinosa. Deus sabe tudo o que vai acontecer por que vê todas as possibilidades infinitas e não por que não seja possível que ocorram outras coisas. O certo é aquilo que vai acontecer que podemos saber pelo conhecimento das suas causas precedentes e o necessário só é aquilo cujo contrário implique contradição. As verdades necessárias se fundam na possibilidade ou impossibilidade das próprias essências sem contarmos com a vontade livre das criaturas ou de Deus.

\section{Interpretação da liberdade em Leibniz}

A liberdade da forma como é entendida comumente muitas vezes se confunde com o indeterminismo, com o caos ou com a desordem. $O$ fato das coisas acontecerem por uma razão não as torna necessárias. Se antes o homem acreditava que os deuses provocavam os raios e as tempestades por sua livre vontade, quando começaram a tentar entender o porquê tiveram que pensar em um mundo de causa e efeito. Pois se tudo é arbitrário que poder tem o homem de agir livremente. Com Leibniz fica mais evidente aquilo que ficou confuso em Descartes e Espinosa, essa mecânica do mundo de que maneira afeta a nossa liberdade? O mundo não é menos livre por serem as 
coisas diferentes do que queremos, pois se tudo fosse conforme nosso arbítrio nós não teríamos por que querer uma coisa e não outra, pois nada em nós haveria de impulsionar-nos a desejar o que quer que seja. Considerando isso o universo não poderia existir sem algo de necessário, para haver existência é necessário que haja a essência. É essa a razão de Descartes, Espinosa e Leibniz escreverem sobre a natureza das paixões humanas, pois entendem haver uma causa para sentirmos esta paixão e não outra qualquer e refletem sobre esse mecanismo que dá a alma o poder de resistir ou ceder às paixões. Agostinho nada fala de como podemos fazer para seguir a virtude e evitar o vício apenas diz que devemos fazê-lo, embora possamos não fazer.

E a filosofia de Leibniz pode responder a de Espinosa quanto ao problema da liberdade causal. Não há liberdade no sentido de que tudo procede de uma causa que vem de outra causa, sempre havendo uma causa anterior até a causa primeira e nada ocorrendo de diferente ao que seguimos necessariamente. Com Leibniz responder-se-ia a isso dizendo que as razões inclinam as vontades sem as tornar necessárias, o fato de uma coisa ter uma razão de ser não implica que essa razão delimita a coisa a ser exatamente como é. As coisas podem acontecer de diversas maneiras dês de que isso não entre em contradição com a definição da própria coisa. Do mesmo modo que da definição de círculo seguem-se infinitas possíveis figuras diferentes entre si, mas todas com a definição de ser um círculo. Da mesma causa haveria uma infinidade de efeitos que não entrariam em contradição com a necessidade de vir dessa causa. É isso que tiramos de Leibniz, há uma razão para tudo, mas a conseqüência desta nunca é única possível. Por isso há sempre liberdade. 


\section{CONCLUSÃO:}

\section{A Liberdade Existe?}

No seu livro: Entre Naturalismo E Religião Jürgen Habermas cita a seguinte passagem de Adorno:

"Se os sujeitos empíricos podem realmente agir por liberdade, então a unidade Kantiana da natureza - fundamentada por categorias- está quebrada, porque os próprios sujeitos fazem parte da natureza. Nesse caso, porém, a natureza revelaria uma falha que estaria em contradição com a unidade do conhecimento da natureza, alvo principal das ciências da natureza [...]." (Jürgen Habermas, 2005, pág. 204)

A resposta para Adorno e a conclusão dessa dissertação é inspirada

no próprio Kant. Pois ele foi influenciado notavelmente por Leibniz e seu admirador Christian Wolff. Para Kant não podemos entender a nossa vontade de maneira empírica.

Leibniz declarava que na nossa própria esfera somos pequenas divindades, mas ele não poderia aceitar a teoria de Kant de que a vontade origina a moralidade. (J.B.Schneewind, 2001, pág. 557)

Kant diz que a natureza realiza o desenvolvimento das habilidades

humanas por meio do antagonismo mútuo da sociedade.

Somos naturalmente propensos a discordar, diz Kant na Anthropology, e somente a razão permite que nos movimentemos na direção da paz um com o outro. Nossas tendências para ser livres da interferência dos outros e nossos desejos sexuais podem não conduzir a um conflito sem fim, mas as "manias de honra posse $e$ poder" devem levar a isto, pois só podem ser gratificados na sociedade, embora sua própria natureza requeira que entremos em competição por elas. (J.B.Schneewind, 2001, pág. 564)

O homem é parte da natureza e suas necessidades e inclinações

podem ser explicadas de forma natural, mas a vontade sempre é soberana. A causa disso é que somos dotados da faculdade da razão e quaisquer que sejam os impedimentos e dificuldades sejam da natureza interior ou exterior a 
nós nossa vontade tem em si mesma o poder de fazer sempre uma escolha. A Natureza segue de maneira determinada, mas nós seres conscientes dela somos a única partícula no universo capaz de agir de forma não necessária e somente a força da nossa vontade é capaz de encontrar múltiplas possibilidades em um destino determinado e um fim determinado em um universo de múltiplas possibilidades.

As conclusões que se chegaram com essa dissertação foram a de que o homem dotado de razão tem em seu poder a capacidade de escolher entre o bem e o mal, ou como se queira, de escolher seguir por um caminho ainda que outro seja o caminho tido como certo foi isso que defendeu Agostinho. $O$ homem não pode ser arrastado por uma força que o impila a agir para o mal, pois é dotado de inteligência superior e essa força de sua vontade que é capaz de resistir às tentações do mundo. Descartes acrescenta que o mérito do homem em seguir no caminho escolhido não está apenas na força da sua vontade, mas também no seu conhecimento do melhor caminho, também destaca que ainda que não estejamos de posse das nossas paixões podemos exercer certo domínio sobre elas decidindo quais imagens colocaremos na nossa mente para assim podermos privilegiar certos sentimentos ao invés de outros. Spinoza coloca a nossa liberdade como sendo esse mesmo poder de seguir por determinados sentimentos de virtude e não de outros, embora não tenha entendido o que Descartes disse sobre o poder da alma em dominar de forma indireta o corpo, Spinoza descreve nossas afecções como parte da nossa essência, o que nos faz distinguir que limite tem a liberdade, não somos menos livres por termos que comer e beber, são essas características necessárias que nos fazem sermos animais e não outra coisa. Mas Spinoza 
coloca também o problema central da liberdade ao expor um mundo onde cada coisa é conseqüência de outra e causa de uma terceira a que nos sugere, quer o mundo tenha ou não provindo de uma causa primeira, que caminhamos para um fim determinado sem chance de ir à outra direção. Leibniz resolve esse problema ao diferenciar o certo do necessário, o necessário é o logicamente possível e o certo é o que vai acontecer. Leibniz também coloca a liberdade como um tipo de poder, o que Kant, o qual não foi tratado nessa dissertação, confirma ao colocar a própria moralidade como produto da vontade.

A liberdade existe então por ter a vontade sempre um espaço livre para se determinar quaisquer que sejam os conflitos interiores e as influências externas e existe sem que tenhamos um mundo de acaso, pois ainda que tudo o que há no universo tenha uma causa certa, uma conseqüência certa pode ser exatamente determinada, porque um evento necessário e previsível pode ter infinitas formas ainda que todas elas estejam dentro do que é necessário nenhuma delas pode ser previamente determinada.

\section{BIBLIOGRAFIA}

Agostinho, Santo O Livre Arbítrio; Paulus; São Paulo; 1995

Descartes,René; Discurso do método; Martins Fontes ; São Paulo; 2003

Descartes,René; As paixões da Alma, As Meditações (Os Pensadores); Abril Cultural; São Paulo;1973;

Espinosa, Baruch; Ética, Pensamentos Metafísicos (Os Pensadores); Abril Cultural; São Paulo; 1973;

Leibniz, Gottfried Wilhelm; Discurso de Metafísica (Os Pensadores); Abril Cultural; São Paulo; 1974; 
Leibniz, Gottfried Wilhelm; Novos Ensaios Sobre O Entendimento Humano (Os Pensadores); Abril Cultural; São Paulo; 1996;

Gilson, Étiene; Introdução ao estudo de Agostinho; Paulus/Discurso Editorial; São Paulo; 2007

Habermas, Jürgen; Entre Naturalismo E Religião; Tempo Brasileiro; Rio de Janeiro; 2007

Schneewind, J.B.; A invenção da Autonomia; Editora Unisinos; Rio Grande do Sul; 2001 